\title{
Use of sulfonamides for the treatment of bovine neonatal diarrhea: clinical and performance parameters
}

\author{
Utilização de sulfonamidas para o tratamento de diarreia neonatal \\ bovina: parâmetros clínicos e zootécnicos
}

\author{
Rosana Klaus $^{1}$; Laura Valadão Vieira ${ }^{2}$ (D); Adriane Dalla Costa de Matos ${ }^{2}$; Antônio Amaral Barbosa ${ }^{1}$; \\ Marcio Nunes Corrêa ${ }^{1}$; Rubens Alves Pereira ${ }^{3}$; Eduardo Gulart Xavier ${ }^{1}$; Cássio Cassal Brauner ${ }^{2}$; \\ Francisco Augusto Burkert Del Pino ${ }^{2}$; Viviane Rohrig Rabassa ${ }^{1}$
}

\footnotetext{
${ }^{1}$ Universidade Federal de Pelotas, Departamento de Medicina Veterinária, Núcleo de Pesquisa, Ensino e Extensão em Pecuária, Capão do Leão - RS, Brazil

${ }^{2}$ Universidade Federal de Pelotas, Departamento de Zootecnia, Núcleo de Pesquisa, Ensino e Extensão em Pecuária, Capão do Leão - RS, Brazil

${ }^{3}$ Laboratório IBASA Ltda., Porto Alegre - RS, Brazil
}

\begin{abstract}
This study was developed to evaluate the clinical, hematological, and performance parameters of calves affected by diarrhea caused by the bacterial enteric pathogen Escherichia coli, treated with three different protocols containing sulfonamides. Fourteen Holstein calves were monitored from birth to 60 days of age, and divided into 3 groups. Group $1(\mathrm{n}=5)$ animals were treated with $80 \mathrm{~g}$ of Kaopek ${ }^{\circledR}$, Ibasa, Brazil, administered orally (BM), dissolved in $160 \mathrm{ml}$ of water every $24 \mathrm{~h}$; Group $2(\mathrm{n}=4)$ received IM sulfadiazine and trimethoprim (Ibatrim;, Ibasa, Brazil), and Group $3(\mathrm{n}=5)$ animals were treated with $80 \mathrm{~g}$ of Kaopek $^{\circledR}$, Ibasa, Brazil, which is made up of $16 \mathrm{~g}$ of phthalylsulfathiazole, associated with $2.28 \mathrm{~g}$ neomycin sulfate, $1.6 \mathrm{~g}$ of pectin, and $80 \mathrm{~g}$ of kaolin, dissolved in $160 \mathrm{ml}$ of water and administered every $24 \mathrm{~h}$ by mouth, in addition to sulfadiazine and trimethoprim (Ibatrim', Ibasa, Brazil), at a daily dose of $16 \mathrm{mg} / \mathrm{kg}$ live weight, through IM injection. During the study, the animals were clinically evaluated, and once they were diagnosed with diarrhea, feces samples were collected to identify the bacterial enteric pathogen, antibiogram, polymerase chain reaction (PCR), and coproparasitological exams. Blood samples were collected to evaluate the hematological profile, and the performance profile was monitored weekly. In the clinical examination, all calves presented a reduction in body temperature $\left(<39.2^{\circ} \mathrm{C}\right)$ and some improvement in hydration after treatment $(\mathrm{p}=0,31)$. However, group 2 had a better concentration of lymphocytes and TP concerning the other animals, as well as better performance. Besides, E.coli was detected in $100 \%$ of feces samples. Thus, the therapeutic protocols with sulfonamides used to treat bovine neonatal diarrhea were effective in the clinical improvement of the animals. Nonetheless, the protocol with systemic therapy using sulfadiazine and trimethoprim (Ibatrim ${ }^{\circ}$, Ibasa, Brazil) intramuscularly, provided better performance, with better weight gain, and body development of the animals.
\end{abstract}

Keywords: Antibiotic therapy. Calf. Disease. E. coli.

\section{RESUMO}

Este estudo foi desenvolvido com o objetivo de avaliar parâmetros clínicos, hematológicos e zootécnicos de bezerras acometidas por diarreia provocada pelo agente bacteriano Escherichia coli, tratadas com três diferentes protocolos contendo sulfonamidas. Quatorze bezerras da raça Holandês foram monitoradas do nascimento até os 60 dias de vida e divididas em 3 grupos: Grupo 1 ( $\mathrm{n}=5$ ), animais tratados com a dose de 80g de Kaopek ${ }^{\odot}$, Ibasa, Brasil, por via oral (VO), dissolvido em $160 \mathrm{ml}$ de água a cada 24 horas; Grupo $2(\mathrm{n}=4)$ receberam sulfadiazina e trimetropim (Ibatrim ${ }^{\oplus}$, Ibasa, Brasil), na dose de $16 \mathrm{mg} / \mathrm{Kg}$ de peso vivo, por dia, por via intramuscular (IM); Grupo 3 (n=5) 80g de Kaopek ${ }^{\circledast}$, Ibasa, Brasil, por VO dissolvido em $160 \mathrm{ml}$ de água, a cada 24 horas e com $16 \mathrm{mg} / \mathrm{Kg}$ de peso vivo, por dia, de sulfadiazina e trimetoprim (Ibatrim ${ }^{\ominus}$, Ibasa, Brasil), por via IM. Durante o estudo, os animais foram avaliados clinicamente e a partir do diagnóstico de diarreia foram coletadas amostras de fezes para a identificação do agente bacteriano, antibiograma, reação em cadeia da polimerase (PCR) e exames coproparasitológicos. Amostras de sangue foram coletadas para avaliação do perfil hematológico e o perfil zootécnico foi acompanhado semanalmente. No exame clínico, todas as bezerras apresentaram redução na temperatura corporal $\left(<39,2^{\circ} \mathrm{C}\right)$ e melhora na hidratação após o período de tratamento $(\mathrm{p}=0,31)$, porém 
o grupo 2 obteve maior concentração de linfócitos e PPT em relação aos demais, assim como melhor desempenho zootécnico, além disso em $100 \%$ das amostras de fezes foi detectado $E$. coli. Sendo assim, os protocolos terapêuticos com sulfonamidas utilizados para o tratamento da diarreia neonatal bovina foram eficazes na melhora clínica dos animais. Porém, o protocolo com terapia sistêmica com sulfadiazina e trimetoprim (Ibatrim ${ }^{\bullet}$, Ibasa, Brasil) por via intramuscular proporcionou um melhor desempenho zootécnico, com melhor ganho de peso e desenvolvimento corporal dos animais.

Palavras-chave: Antibioticoterapia. Bezerro. Doenças. E. coli.

Correspondence to:

Laura Valadão Vieira

Universidade Federal de Pelotas, Departamento de Zootecnia,

Núcleo de Pesquisa, Ensino e Extensão em Pecuária

Avenida Eliseu Maciel, S/N, CEP: 96010-900, Capão do Leão -

RS, Brazil

e-mail: lauravieira96@gmail.com

Received: August 31, 2020

Approved: February 23, 2021

How to cite: Klaus R, Vieira LV, Matos ADC, Barbosa AA, Corrêa MN, Pereira RA, Xavier E, Brauner CC, Del Pino FAB, Rabassa VR. Use of sulfonamides for the treatment of bovine neonatal diarrhea: clinical and performance parameters. Braz J Vet Res Anim Sci. 2021;58:e174336. https://doi.org/10.11606/issn.1678-4456.bjvras.2021.174336

\section{Introduction}

Calf rearing is a crucial point in milk production because of the high neonatal mortality rates diagnosed in this period and its negative effects on the future lactating cow. This represents a major challenge to dairy farming systems (Aghakeshmiri et al., 2017). Respiratory and digestive diseases are more prevalent at this time, with diarrhea the one that most affects calves in the first days of life, causing important economic losses, impairing body development and the productive potential of these animals (Aghakeshmiri et al., 2017; Berge et al., 2009).

Neonatal diarrhea causes high mortality rates, ranging from 10 to $34 \%$, being characterized as a multifactorial disease caused by the interaction between failures in the animal's immunity, nutritional status, and infectious pressure of the environment (Feitosa et al., 2001; Renaud et al., 2018). Infectious etiologies are more frequent, and the main enteric pathogens involved are Escherichia coli, Salmonella spp., Clostridium perfringens, Rotavirus, Coronavirus, Eimeria spp., and Cryptosporidium spp. (Athira et al., 2018; Blanchard, 2012; Holschbach \& Peek, 2018; Lorenzetti et al., 2014). Although some authors show high economic losses and difficulty in coping with this disease, fighting the etiological enteric pathogen properly can significantly reduce its incidence and, consequently, damage to production (Berge et al., 2009; Constable, 2009). Thus, the treatment of neonatal diarrhea aims to decrease the proliferation of the causative pathogen, together with the reduction of fluid and electrolyte loss (Constable, 2009).

Drug misuse for many decades has resulted in a wide variety of resistant microorganisms, which challenge the effectiveness of antibacterial treatments, both in animals and humans (Chouchani et al., 2018; Constable, 2009). However, Constable (2009) states that the use of antibiotics in the treatment of bovine neonatal diarrhea is necessary due to the overgrowth of commensal bacteria in the small intestine, which can cause clinical complications associated with bacteremia. Nonetheless, the use of antimicrobial agents is not always beneficial. For example, viral and parasitic diarrhea can delay the improvement process in the clinical setting. Therefore, the choice of antibiotic therapy must be justified by the identification of etiological agents, changes in animal behavior, and severe clinical manifestations, such as fever and reduced food intake (Gomez et al., 2017).

Another factor that can influence the effectiveness of the treatment is the route of drug administration. Although there is a recommendation for the use of sulfonamides orally and intramuscularly, the pros and cons of administration via different routes and the speed at which the therapeutic effects are desired must be considered (Lopes et al., 2006).

Given the above, this study aims to evaluate the clinical, hematological, and performance parameters of calves affected by diarrhea caused by the bacterial enteric pathogen Escherichia coli, treated with three different protocols containing sulfonamides.

\section{Material and Methods}

This study was approved by the Ethics Committee for Animal Experimentation ECAE-UFPEL(number 23110.041629/2018-03).

\section{Location and characterization of the calves rearing system}

The experiment was carried out on a dairy farm of a complete cycle, located in the south of Rio Grande do Sul, Brazil ( $32^{\circ} 16^{\prime} \mathrm{S}, 52^{\circ} 32^{\prime} \mathrm{E}$ ). The study evaluations took place in the calves sector, where the animals were kept in an intensive system of production, under the same management conditions, housed on an elevated shed with individual pens, daily sanitized, receiving six liters of milk per day (divided into two meals), with free access to water and concentrate. 


\section{Evaluated animals and experiment design}

Fourteen Holstein calves were used from their first day of age. After birth, colostrum was carried out naturally, keeping the calf with the cow for $24 \mathrm{~h}$. Afterward, total plasma protein concentration (TP) was evaluated to determine the proper passive transfer of maternal immunity, considering the minimum concentration of $5.5 \mathrm{~g} / \mathrm{dL}$ (Blanchard, 2012).

The calves were monitored daily from birth to 60 days of age and divided randomly into 3 groups according to the diagnosis of neonatal diarrhea. The clinical case detection was performed based on the evaluation of the animals' behavior, clinical examination, and feces score according to the classification used by McGuirk (2008), with scores 2 and 3 characterized by diarrheic feces. Thus, according to the mentioned criteria, the groups were:

Group $1(n=5)$ : animals treated with $80 \mathrm{~g}$ of Kaopek ${ }^{\circledR}$, Ibasa, Brazil, which is composed of $16 \mathrm{~g}$ of phthalylsulfathiazole associated with $2.28 \mathrm{~g}$ of neomycin sulfate, $1.6 \mathrm{~g}$ of pectin, and 80 $\mathrm{g}$ of kaolin, administered by mouth, dissolved in $160 \mathrm{ml}$ of water, every $24 \mathrm{~h}$;

Group $2(\mathrm{n}=4)$ : animals treated with sulfadiazine and trimethoprim (Ibatrim ${ }^{\circledR}$, Ibasa, Brazil), at a daily dose of $16 \mathrm{mg} /$ $\mathrm{kg}$ live weight, through IM injection. There are $40 \mathrm{~g}$ of sulfa and $8 \mathrm{~g}$ of trimethoprim in $100 \mathrm{ml}$ of this product;

Group $3(n=5)$ : animals treated with 80 g of Kaopek ${ }^{\circledR}$, Ibasa, Brazil, which is made up of $16 \mathrm{~g}$ of phthalylsulfathiazole, associated with $2.28 \mathrm{~g}$ neomycin sulfate, $1.6 \mathrm{~g}$ of pectin, and $80 \mathrm{~g}$ of kaolin, dissolved in $160 \mathrm{ml}$ of water and administered every $24 \mathrm{~h}$ by mouth, in addition to sulfadiazine and trimethoprim (Ibatrim ${ }^{\circledR}$, Ibasa, Brazil), at a daily dose of $16 \mathrm{mg} / \mathrm{kg}$ live weight, through IM injection. In $100 \mathrm{ml}$ of Ibatrim ${ }^{\circledR}$, there are $40 \mathrm{~g}$ of sulfa and $8 \mathrm{~g}$ of trimethoprim.

All evaluated treatments lasted for 5 days. The animals received support therapy BM with an electrolytic and energetic solution twice a day, according to the farm protocols, besides $1.1 \mathrm{mg} / \mathrm{kg}$ of flunixin meglumine (Flumedin ${ }^{\oplus}$, Jofadel, Brazil), intramuscularly for 3 days.

Calves with $\mathrm{TP}<5.5 \mathrm{~g} / \mathrm{dL}$ in the first $24 \mathrm{~h}$ of age, as well as animals with diarrheic feces and fever (temperature $>39.2^{\circ} \mathrm{C}$ ) and/or leukocytosis were excluded from this study.

\section{Evaluated clinical parameters}

Given the diagnosis of diarrhea, where the scores found in Table 1 were considered, clinical evaluations were performed on the diagnosis day (day 0 ) and the following days (days 3,5 , and 7 ). The following parameters were evaluated: heart rate (HR), respiratory rate (RR), body temperature $\left(\mathrm{T}^{\circ} \mathrm{C}\right)$, mucosal color, and the level of dehydration (through skin turgor), and capillary refill time (CRT) (Feitosa, 2014).
Table 1 - Stool score classification (McGuirk, 2008)

\begin{tabular}{cc}
\hline Stool score & Characteristics \\
\hline 1 & Pasty stools \\
2 & $\begin{array}{c}\text { Pasty stools with more water and feces adhered to } \\
\text { the perineum and tail }\end{array}$ \\
3 & $\begin{array}{c}\text { Liquid stools with fecal content adhered to the } \\
\text { perineum and tail }\end{array}$ \\
\hline
\end{tabular}

\section{Feces samples}

Samples were collected on days 0 and 7 from all evaluated animals (totaling 28 samples), for score evaluations, coproparasitological exam, microbiological exam, antibiogram, and polymerase chain reaction (PCR). The microbiological culture and the antibiogram were carried out in the Regional Diagnostic Laboratory (RDL), the coproparasitological exam in the Food Microbiology Laboratory (DCTA), all located at the Federal University of Pelotas (UFPEL, Pelotas, Brazil).

The feces were placed in Petri dishes containing blood agar and MacConkey agar.

The formed bacterial colonies were evaluated for Gram stain as negative or positive (Alterthum \& Trabulsi, 2015). After that, a sequence of biochemical tests was carried out: Sulfide production (H2S), indole production and motility, TSI (triple sugar and iron), sorbitol, and inositol, aiming to analyze the bacterial metabolism, more specifically, the ability to degrade certain substrates and/or produce gases (Alterthum \& Trabulsi, 2015). After the pathogen identification and characterization, the in vitro sensibility test was performed, antibiogram following the methodology of Quinn et al. (2005). In the isolated ones confirmed as E. coli, virulence genes were screened by PCR (Crăciunaş et al., 2012; Paton \& Paton, 1998).

\section{Blood samples}

Blood samples were collected on days 0,3 , and 7 (concerning the diarrhea diagnosis) to evaluate the hematological profile, fibrinogen, and TP. The hematological analysis was performed in an automated analyzer (BC 2800 Vet, Mindray') and the leukocyte differential was made with stained blood smear, after counting 100 cells, in optical microscopy (González \& Silva, 2018). The plasma fibrinogen content was obtained by the heat precipitation method and by a refractometer reading. The TP concentrations were determined through commercial reagents (Labtest, Belo Horizonte, Brazil) and the sample reading was performed in a visible light spectrophotometer (BioEspectro SP 220, Bioespectro, Curitiba, Brazil) (González \& Silva, 2018). 


\section{Performance monitoring}

The measurements of the thoracic perimeter were carried out weekly, using a flexible tape, while the withers height and rump width were measured with a ruler graduated in centimeters, from day 7 to 30 . Still, together with the mentioned evaluations, the animals were weighed using a weight tape. However, this analysis continued to be performed weekly until 60 days, aiming to obtain the weight gain mean from birth to weaning.

\section{Statistical analysis}

Residual distribution was assessed for normality by the Shapiro-Wilk test and homoscedasticity by graphic evaluation (residual vs predictive value). The data were analyzed using the SAS Institute statistical program (SAS Institute INC., 2009) using the MIXED procedure for repeated measures, with group, days and their interaction (group * days) evaluated as fixed effects and animal being treated as a random effect. The autoregressive variancecovariance matrix was used to analyze repeated measures in clinical examination data, stool score, hematological, and performance parameters. The comparison of means was performed using the Tukey test, considering the statistically significant difference $\mathrm{P}<0.05$ and trend $\mathrm{P}=0.06 .3$.

\section{Results and Discussion}

Although there are several enteric pathogens responsible for causing neonatal diarrhea, in this study, in $100 \%$ of the analyzed feces samples the presence of Escherichia coli was detected, regardless of the collecting time. The culture and biochemical tests were negative for the presence of Salmonella, and the presence of Cryptosporidium was not detected in the centrifugal sedimentation test. The viral pathogens (Rotavirus and Coronavirus) were not detected either.

From the 28 collected samples the PCR examination detected the presence of genes of hemolysin virulence (hlyA), Shiga toxin (stx1), and intimin (eae) in $39.28 \%, 10.71 \%$, and $10.71 \%$ of the stool samples, respectively, especially observed in the collections of day 7. The thermostable toxin A (st A) was present in $10.71 \%$ of the collected feces. Yet $28.59 \%$ of the samples were negative for these genes as shown by Klaus et al. (2020). The found genes are characteristic of enterohemorrhagic E.coli (EHEC), Shiga toxin-producing E. coli (STEC), enterotoxigenic (ETEC), and enteropathogenic E. coli (EPEC), respectively, with the STEC and EHEC present in $2.7 \%$ to $50 \%$ of neonatal diarrhea, while the occurrence of ETEC can be detected in up to $30 \%$ of samples, according to what was reported by Andrade et al. (2012). In this study, the main virulence gene found was hlyA, in $28.59 \%$ of samples. Its presence is determined by the EHEC and its action is characterized by the ability to cause a lesion in the intestinal cells, due to the pro-inflammatory changes, damaging, among others, the absorption of nutrients (Badoue et al., 2016).

The calves affected by neonatal diarrhea can have gastrointestinal disorders, reducing the nutrients intake and absorption, consequently decreasing the weight gain and causing possible future negative effects for the animal (Aghakeshmiri et al., 2017). Although the disease can bring about several harms to the animal, the use of antibiotics needs to be carefully monitored. Gomez et al. (2017) applied an algorithm in two farms, in which only calves affected by diarrhea associated with systemic signs, such as fever, were treated, and after that, some reduction in the use of antibiotics in the studied farms was observed, and an increase in the concentration of beneficial bacteria to intestinal health, especially the Lachnospiraceae and Ruminococcaceae families.

Yet, recent studies have advocated not using antibiotics for diseases caused by E.coli, according to what is reported by Schukken et al. (2011). However, Bashahun \& Amina (2017) recommend the therapy using antimicrobials, mainly due to dehydration and loss of electrolytes caused by the disease, which can change the acid-base balance leading to a high mortality rate in diarrheic animals.

The majority of studied calves were affected with diarrhea in the first 5 days and were monitored from the first to the seventh day of treatment concerning feces score. In these evaluations, all animals had a feces score of 3 at the onset of the disease, meaning there was a likelihood to cause dehydration and blood $\mathrm{pH}$ imbalance, which, according to what was mentioned above, justifies the treatment (Figure 1). After using medication for five days, the scores returned to physiological conditions, except for group 3 (treated with oral + injection sulfonamides), which presented score 2 (diarrheic feces) at day 5 , differing from group $1(\mathrm{p}<0.05)$, which was only treated with sulfonamides by mouth. This difference between groups 1 and 3 can be related to factors that interfered in motility and intestinal absorption, such as stress and food causes, or the ones related to management (Foster \& Smith, 2009). However, in the evaluations carried out on day 7 , all animals treated with the three different protocols had normal feces.

According to Foster \& Smith (2009), calves affected with neonatal diarrhea constantly produce watery feces, clinically characterized by different levels of dehydration, apathy, inappetence, and changes in vital signs that would 
probably cause some changes in the clinical examination. In this study, although there was no statistical difference in clinical parameters, all animals had tachypnea at the moment of the diagnosis, and the RR was characterized as an important parameter since its elevation is associated with a compensatory mechanism of metabolic acidosis. Such a condition (i.e., metabolic acidosis) is commonly observed in diarrheic calves (Blanchard, 2012).

Furthermore, all animals in this study had a body temperature equal to or above $39.2^{\circ} \mathrm{C}$ at the moment of the diarrhea diagnosis. This parameter is considered an important criterion to define the use of antibiotics (Constable, 2009). After treatment, both RR and the rectal temperature reduced to the values considered ideal for the animal category, demonstrating the efficiency of the protocols used.

The hematological profile plays an important role in the prognosis because it demonstrates the immune response

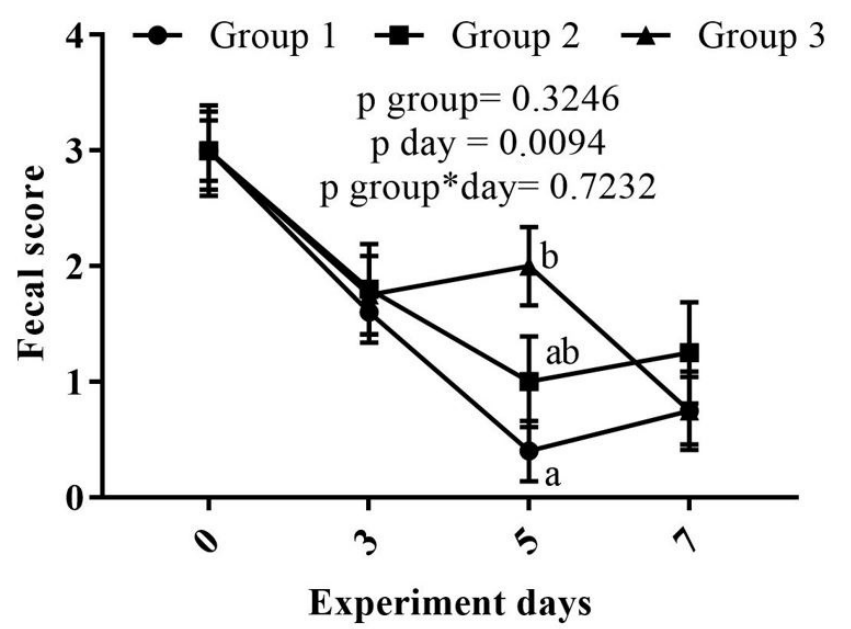

Figure 1 - Stool score of dairy heifers affected by neonatal diarrhea and submitted to different therapeutic protocols containing sulfonamides. Group 1: Animals submitted to oral administration of sulfonamides; Group 2: Animals submitted to injectable administration of sulfonamides; Group 3: Animals submitted to oral and injectable sulfonamide administration. ${ }^{\mathrm{a}, \mathrm{b}}$ Different letters indicate statistical difference between groups. of the animal, as well as its contribution to choose the appropriate therapy (Benesi et al., 2012; Knowles et al., 2000). All studied animals presented a difference in the lymphocyte blood levels, although the concentrations kept within the reference values (Table 2; Figure 2), there was one of this parameter in group 2 (group 1: $4798.40 \pm 247.03$, group 2: $5586.00 \pm 184.21$, group 3:2 $4808.50 \pm 290.23$ ), from the third day of treatment. Possibly, this can be related to the animals' age, because the levels of lymphocytes gradually increase according to age range, achieving the neutrophillymphocyte ratio which is regarded as normal for adult animals at around 15 days of age (Knowles et al., 2000).

$\mathrm{TP}$ is a marker that increases in infectious or inflammatory processes, as well as in dehydration conditions (Rosa et al., 2018). In this context, the blood levels of TP were higher in groups 2 and 3 , a result that is related to the inflammatory process as a response to the enteric pathogen, not the dehydration, as this change was not clinically observed (Figure 3) (Foster \& Smith, 2009; Rosa et al., 2018). It is important to highlight that some bacteria involved in diarrhea have certain virulence factors that cause or stimulate an acute inflammatory response in the intestinal mucosa (Foster \& Smith, 2009). The other parameters did not differ among groups.

The leukocyte profile, as well as temperature, were considered as criteria of inclusion in the study. Although there was no difference among groups $(\mathrm{p}=0,83)$, Figure 2 shows that all groups had leukocyte levels above the physiological one at moment zero. From the beginning of the treatment, there was a reduction to normal levels (collections performed at days 3 and 7 concerning diarrhea diagnosis), except for group 1, which presented leukocytosis at day 7, two days after the end of treatment. Furthermore, segmented neutrophil levels above the physiological one were also observed at the onset of diarrhea, reducing to normal levels after treatment.

Table 2 - Blood parameters of dairy heifers affected by neonatal diarrhea submitted to different therapeutic protocols containing sulfonamides. Pelotas, Rio Grande do Sul, Brazil, 2020, at 10:00 am

\begin{tabular}{|c|c|c|c|c|c|c|c|}
\hline \multicolumn{7}{|c|}{ Groups p value } & \multirow{2}{*}{ Ref. value } \\
\hline Param. & Group $1^{1}$ & Group $2^{2}$ & Group $3^{3}$ & $\mathbf{G}^{4}$ & $D^{5}$ & $G * D$ & \\
\hline Leuko. & $11701 \pm 2169.32$ & $10768 \pm 1068.94$ & $11557 \pm 934.55$ & 0.83 & 0.09 & 0.90 & $4.000-12.000$ \\
\hline NR & $149.27 \pm 45.69$ & $151.27 \pm 50.76$ & $128.58 \pm 17.09$ & 0.85 & 0.07 & 0.86 & 0-120 \\
\hline NS & $5496.60 \pm 1798.36$ & $4004.20 \pm 821.42$ & $5394.58 \pm 964.65$ & 0.49 & 0.06 & 0.87 & $600-4.000$ \\
\hline Lymph. & $4798.40 \pm 247.03^{a}$ & $5586.00 \pm 184.21^{b}$ & $4808.50 \pm 290.23^{a}$ & 0.02 & 0.01 & 0.98 & $2.500-7.500$ \\
\hline TP & $6.78 \pm 0.12^{\mathrm{a}}$ & $7.73 \pm 0.16^{b}$ & $8.03 \pm 0.10^{b}$ & $<0001$ & 0.27 & 0.70 & $>5.5 \mathrm{~d} / \mathrm{dL}$ \\
\hline Fibrin. & $700.00 \pm 53.33$ & $586.67 \pm 38.87$ & $716.67 \pm 39.67$ & 0.06 & 0.99 & 0.69 & $300-700$ \\
\hline
\end{tabular}

${ }^{1}$ Animals submitted to oral administration of sulfonamides; ${ }^{2}$ Animals submitted to injectable administration of sulfonamides; ${ }^{3} \mathrm{Animals}$ submitted to oral and injectable sulfonamide administration; ${ }^{4} \mathrm{Group} ;{ }^{5}$ Day. Leuko.: Total leukocytes (/ mm3); NR: Neutrophil rods (/ mm3); NS: segmented neutrophils (/ mm3); Lymph.: Lymphocytes (/ mm3); TP: Total Proteins (g/dL); Fibrin.: Fibrinogen (g/dL). ${ }^{a, b}$ Different letters indicate statistical difference between groups. References value, Kaneko et al. (2008). 
a)

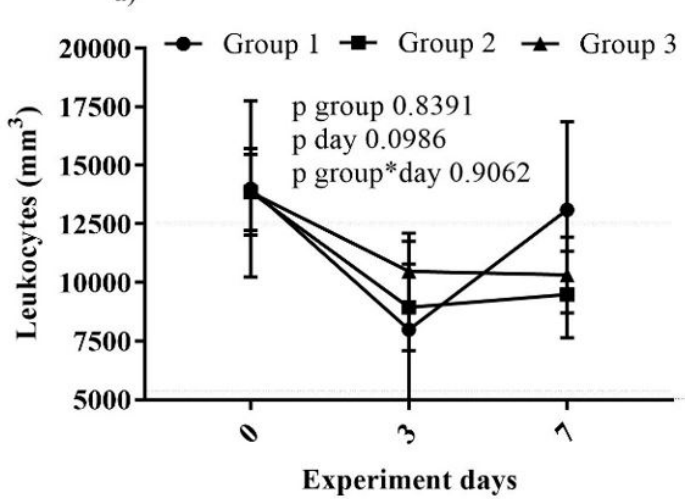

b) $\rightarrow$ Group $1 \rightarrow$ Group $2 \neq$ Group 3

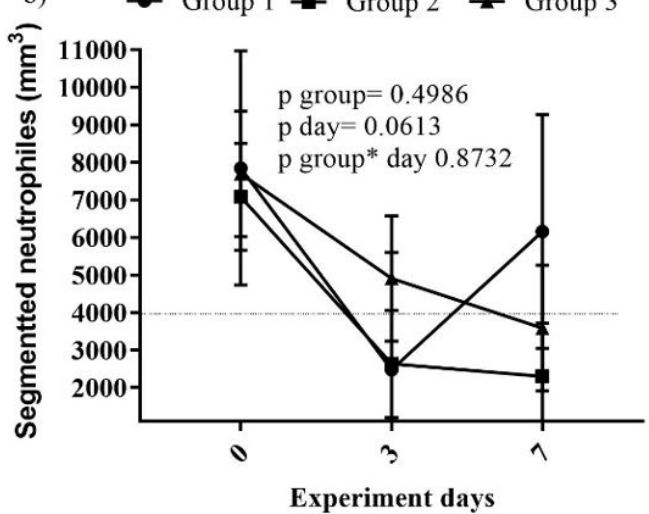

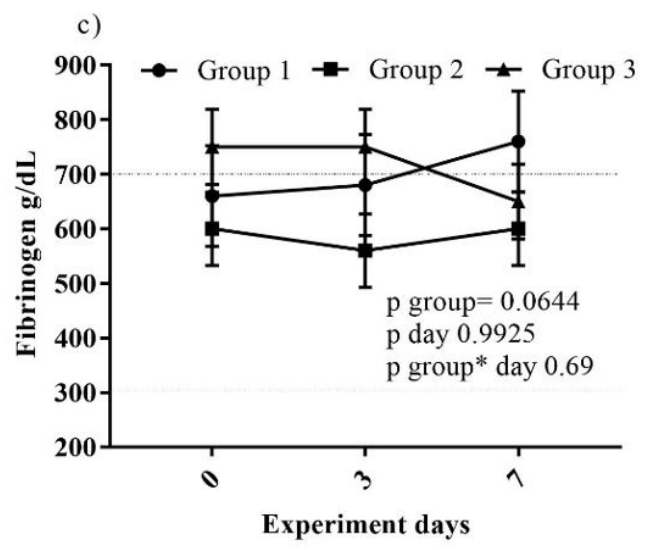

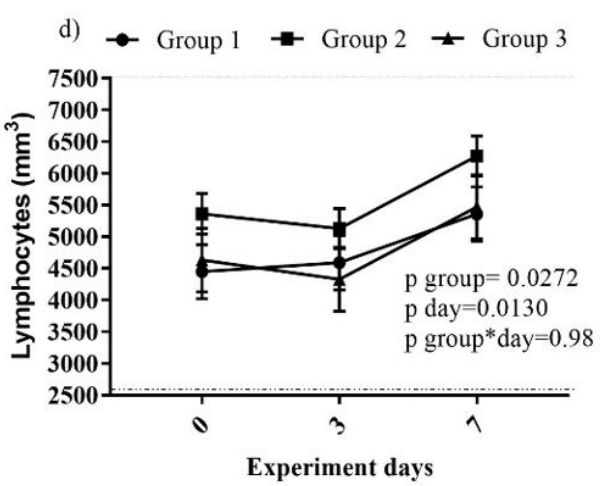

Figure 2 - Blood levels of total leukocytes, segmented neutrophils, fibrinogen, and lymphocytes from dairy calves affected by neonatal diarrhea and submitted to different protocols treatments containing sulfonamides. Group 1: Animals submitted to oral administration of sulfonamides; Group 2: Animals submitted to injectable administration of sulfonamides; Group 3: Animals submitted to oral and injectable sulfonamide administration. The dashed line indicates the physiological interval, according to Kaneko et al. (2008). ${ }^{\mathrm{a}, \mathrm{b}, \mathrm{c}, \mathrm{d}}$ Different letters indicate a statistical difference between groups.

p group $<0.0001$

$\mathrm{p}$ day $=0.2765$

p group*dai $=0.70$

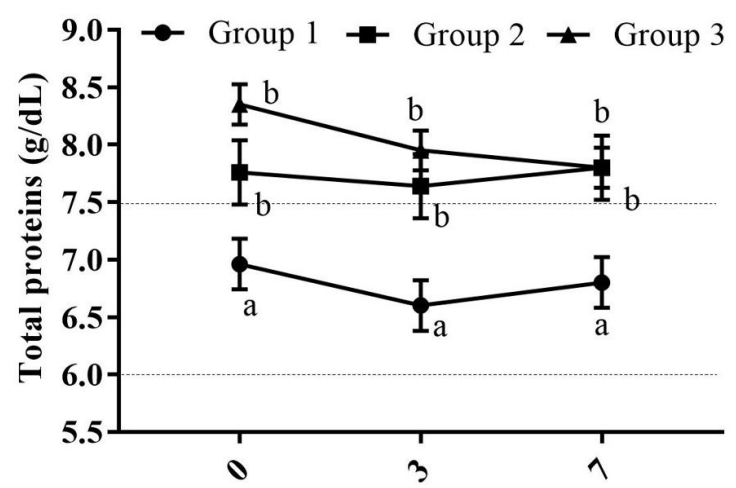

Experiment days

Figure 3 - Total plasma proteins of dairy heifers affected by neonatal diarrhea and submitted to different therapeutic protocols containing sulfonamides. Group 1: Animals submitted to oral administration of sulfonamides; Group 2: Animals submitted to injectable administration of sulfonamides; Group 3: Animals submitted to oral and injectable sulfonamide administration. ${ }^{\mathrm{a}, \mathrm{b}}$ Different letters indicate a statistical difference between groups; Dashed line indicates the physiological interval, according to Kaneko et al. (2008).
However, group 1 had neutrophilia on day 7, two days after the end of treatment (Table 2, Figure 2).

Given the results, it is possible to observe that at first all the therapeutic protocols used in this study were effective to stop diarrhea caused by E.coli. However, at the end of treatment, calves treated with protocols 1 and 2 showed signs of relapse, with the appearance of leukocytosis with neutrophilia. In treatment 1 , animals received phthalylsulfathiazole associated with neomycin orally, in protocol 2, besides the oral treatment, sulfadiazine and trimethoprim were administered IM. Protocol 3 only had sulfadiazine and trimethoprim administered IM. This way, it is possible to note that all animals were provided with therapies using broadspectrum bactericidal substances. Sulfas act to inhibit the synthesis of folic acid, which is used in the process of bacterial cell growth (bacteriostatic). However, when associated with trimethoprim, it becomes bactericidal (Léo et al., 2009; Opal \& Pop-Vicas, 2015). Neomycin, in turn, is an aminoglycoside that acts on the protein synthesis causing bacterial death (Almenara et al., 2008). 
Therefore, the main difference among treatments is the routes of administration and the active principles, since sulfa was associated with other antimicrobials and these factors can be connected with the different animals' responses to treatment.

When drugs are administered orally, they can be partially inactivated by the abomasal $\mathrm{pH}$, which can result in underdosing (Papich, 2016). Thus, the involved bacteria might have developed resistance to the orally administered antimicrobial, neomycin sulfate, which could have caused only the inhibitory effect on the bacteria growth, and this, due to intrinsic factors, started to grow again and cause injury. This may have been the reason why there was less effectiveness in group 1 (oral treatment, and only local action) when compared to the other groups (Trefz et al., 2017). Therefore, treatments only administered by mouth can culminate with bacterial resistance, turning the protocol more expensive and less costly when not associated with systemic therapy, as shown by Papich, (2016).

Animals treated with protocol 2 (sulfa with trimethoprim IM), had better performance with greater average weight when compared to the other groups (Figure 4). Also, they had better results in body development during the neonatal period. The result can be attributed to factors such as reduction of stressful management with oral drug administration, together with the fact that sulfadiazine associated with trimethoprim IM provides a bactericidal effect faster than phthalylsulfathiazole, neomycin sulfate administered orally, since this route can suffer inactivation (Papich, 2016; Spinosa et al., 2002). The IM faster action happens because the vascularization of the tissue allows the drug to be absorbed quickly, minimizing systemic inflammations caused by bacterial colonization early in the calf's life (Araújo et al., 2015; Cassiani et al., 2003).

Results show that protocol 3 was the best to fight the disease, using active principles phthalylsulfathiazole, neomycin sulfate, sulfadiazine, and trimethoprim, besides pectin, and the latter can potentially protect the intestinal mucosa, reducing cases of diarrhea and/or speeding the recovery of this disease (Moreira et al., 2008). However, protocol 2 was more effective regarding the performance of treated animals, even though the clinical condition of diarrhea is responsible for causing changes in the intestinal mucosa that damage the absorptive capacity affecting weight gain and body development (Foster \& Smith, 2009).

Studies point out that calves affected with diarrhea have reduced weight gain in $10.7 \mathrm{Kg}$ at weaning when compared with healthy calves (Aghakeshmiri et al., 2017).
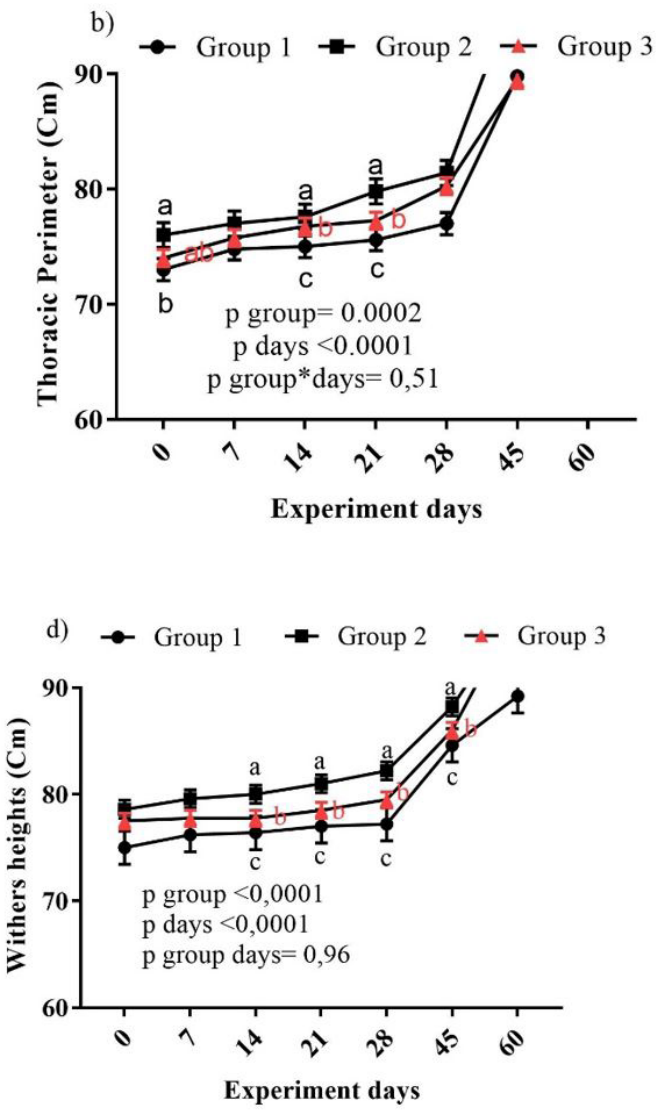

Figure 4 - Zootechnical parameters during the first 60 days of life in dairy heifers affected by neonatal diarrhea submitted to different protocol treatments containing sulfonamides. Group 1: Animals submitted to oral administration of sulfonamides; Group 2: Animals submitted to injectable administration of sulfonamides; Group 3: Animals submitted to oral and injectable sulfonamide administration. ${ }^{\mathrm{a}, \mathrm{b}, \mathrm{c}, \mathrm{d}}$ Different letters indicate statistical difference between groups. 
This developmental delay can damage the mammary gland that is developed within the first nine months of age, being highly influenced by the animal's weight gain. Then, it is estimated that animals presenting delayed development tend to become less efficient milk producers (Botteon et al., 2008). Corroborating this, a study by Aghakeshmiri et al. (2017) showed that calves having neonatal diarrhea increased age at first calving, due to a lower growth during the breeding period, reducing their productive performance. In this context, it is important to establish effective treatment alternatives, enabling feed conversion, and promoting animals' weight gain (Botteon et al., 2008).

Given the above, protocol 2 can be considered as more effective, because animals that received this treatment presented better performance, although they were exposed to fewer amounts of active principles when compared with group 3 animals. Besides, not using oral drug administration minimizes the stress caused by these animals' management. Although the animals of group 2 have presented leukocytosis with neutrophilia, their feces were normal, according to the assessment carried out on day 7 after treatment.

To carry out this study, all animals affected with diarrhea on the farm, during the assessment period were selected, totaling 14 calves. All tested protocols had sulfa, although it was administered through different routes, besides involving other active principles. Although an evaluation of a control group is recommended, the mortality risk turns it to be unfeasible to adopt this methodology on commercial farms. Regardless of these factors, the results seem to show that even considering these facts, all protocols

\section{References}

Aghakeshmiri F, Azizzadeh M, Farzaneh N, Gorjidooz M. Effects of neonatal diarrhea and other conditions on subsequent productive and reproductive performance of heifer calves. Vet Res Commun. 2017;41(2):107-12. http:// dx.doi.org/10.1007/s11259-017-9678-9. PMid:28160198.

Almenara FS, Ribeiro L, Matsuno RMS, Lopes RMG, Oliveira TS, Pereira DM. Ototoxicidade do aminoglicosídeo. Rev Cient Elet Med Vet. 2008;5(11):1-5.

Alterthum CL, Trabulsi LR. Microbiologia. 6. ed. São Paulo: Atheneu; 2015. 920 p.

Andrade GI, Coura FM, Santos EL, Ferreira MG, Galinari GC, Facury Filho EJ, de Carvalho AU, Lage AP, Heinemann MB. Identification of virulence factors by multiplex PCR were effective, and the one associating oral and systemic therapies stood out.

\section{Conclusion}

The therapeutic protocols with sulfonamides used for the treatment of neonatal calves with diarrhea were effective in their clinical improvement. However, the protocol with systemic therapy with sulfadiazine and trimethoprim (Ibatrim ${ }^{\oplus}$, Ibasa, Brazil) administered intramuscularly, provided better performance, with better weight gain and body development.

\section{Conflict of Interest}

The authors declare that they do not have any conflict of interest.

\section{Ethics Statement}

This study was approved by the Ethics Committee for Animal Experimentation ECAE-UFPEL (number 23110.041629/2018-03).

\section{Acknowledgements}

The authors would like to thank the Federal University of Veterinary Medicine Department Pelotas University (PPGZ - UFPel, Pelotas, Brazil) and COREMU for financial support. A special thanks to the commercial property Granjas 4 Irmãos (Rio Grande, Brazil) for the availability, and the Ibasa Laboratory for the partnership formed.

in Escherichia coli isolated from calves in Minas Gerais, Brazil. Trop Anim Health Prod. 2012;44(7):1783-90. http:// dx.doi.org/10.1007/s11250-012-0139-8.

Araujo G, Yunta C, Terré M, Mereu A, Ipharraguerre I, Bach A. Intestinal permeability and incidence of diarrhea in newborn calves. J Dairy Sci. 2015;98(10):7309-17. http:// dx.doi.org/10.3168/jds.2015-9666. PMid:26210273.

Athira CK, Milton AAP, Reddy A, Mekhemadhom Rajendrakumar A, Abhishek, Verma MR, Kumar A, Nagaleekar VK, Agarwal RK. Diversity of toxin-genotypes among Clostridium perfringens isolated from healthy and diarrheic neonatal cattle and buffalo calves. Anaerobe. 2018;49:99102. http://dx.doi.org/10.1016/j.anaerobe.2018.01.001. PMid:29307649. 
Badoue IMA, Morabito S, Najafifar A, Mazandarani E. Molecular characterization of enterohemorrhagic Escherichia coli hemolysin gene (EHEC-hlyA)-harboring isolates from cattle reveals a diverse origin and hybrid diarrheagenic strains. Infect Genet Evol. 2016;39:342-8. http://dx.doi. org/10.1016/j.meegid.2016.02.002. PMid:26855346.

Bashahun GM, Amina A. Colibacillosis in calves: a review of literature. J Anim Sci Vet Med. 2017;2(3):62-71. http:// dx.doi.org/10.31248/JASVM2017.041.

Benesi FJ, Teixeira CM, Lisboa JA, Leal ML, Birgel EH Jr, Bohland E, Mirandola RM. Eritrograma de bezerras sadias, da raça Holandesa, no primeiro mês de vida. Pesq Vet Bras. 2012;32(4):357-60. http://dx.doi.org/10.1590/ S0100-736X2012000400014.

Berge ACB, Moore DA, Besser TE, Sischo WM. Targeting therapy to minimize antimicrobial use in preweaned calves: effects on health, growth, and treatment costs. J Dairy Sci. 2009;92(9):4707-14. http://dx.doi.org/10.3168/jds.20092199. PMid:19700735.

Blanchard PC. Diagnostics of dairy and beef cattle diarrhea. Vet Clin North Am Food Anim Pract. 2012;28(3):443-64. http://dx.doi.org/10.1016/j.cvfa.2012.07.002. PMid:23101670.

Botteon RDCCM, Botteon PDTL, Santos JDCB Jr, Pinna MH, Lóss ZG Freqüência de diarréia em bezerros mestiços sob diferentes condições de manejo na região do médio Paraíba Rio de Janeiro e Minas Gerais. Braz J Vet Res Anim Sci. 2008;45(2):153-60. http://dx.doi.org/10.11606/ issn.1678-4456.bjvras.2008.26712.

Cassiani SHDB, Benfati FBDS, Dias DC, Zem-Mascarenhas SH, Zanetti ML. Development of an online course on medication administration. Rev Esc Enferm USP. 2003;37(3):44-53. http://dx.doi.org/10.1590/S0080-62342003000300006. PMid:14686047.

Chouchani C, Rolain JM, Ghrairi T. Recent advances in antimicrobial and bacterial resistance. Int J Antimicrob Agents. 2018;52(6):869-70. http://dx.doi.org/10.1016/j. ijantimicag.2018.11.021. PMid:30551777.

Constable PD. Treatment of calf diarrhea: antimicrobial and ancillary treatments. Vet Clin North Am Food Anim Pract. 2009;25(1):101-20. http://dx.doi.org/10.1016/j. cvfa.2008.10.012. PMid:19174285.

Crăciunaş C, Keul AL, Flonta M, Cristea M. DNA-based diagnostic tests for Salmonella strains targeting hilA, agfA.
spvC and sefC genes. J Environ Manage. 2012;95(Suppl):S15-8. http://dx.doi.org/10.1016/j.jenvman.2010.07.027. PMid:21071133.

Feitosa FLF, Birgel EH, Mirandola RMS, Perri SHV. Diagnóstico de falha de transferência de imunidade passiva em bezerros através da determinação de proteína total e de suas frações eletroforéticas, imunoglobulinas $\mathrm{G}$ e $\mathrm{M}$ e da atividade da gama glutamil transferase no soro sanguíneo. Cienc Rural. 2001;31(2):251-5. http://dx.doi.org/10.1590/ S0103-84782001000200010.

Feitosa, F. Exame físico geral ou de rotina. Semiologia Veterinária: A arte do diagnóstico, 2014;3:51-57.

Foster DM, Smith GW. Pathophysiology of diarrhea in calves. Vet Clin North Am Food Anim Pract. 2009;25(1):13-36. http://dx.doi.org/10.1016/j.cvfa.2008.10.013. PMid:19174281.

Gomez DE, Arroyo LG, Poljak Z, Viel L, Weese JS. Implementation of an algorithm for selection of antimicrobial therapy for diarrhoeic calves: impact on antimicrobial treatment rates, health and faecal microbiota. Vet J. 2017;226:15-25. http:// dx.doi.org/10.1016/j.tvjl.2017.06.009. PMid:28911836.

González FHD, Silva SC. Patologia clínica veterinária: texto introdutório. Porto Alegre: Universidade Federal do Rio Grande do Sul; 2018. 342 p.

Holschbach CL, Peek SF. Salmonella in dairy cattle. Vet Clin North Am Food Anim Pract. 2018;34(1):133-54. http:// dx.doi.org/10.1016/j.cvfa.2017.10.005. PMid:29224803.

Kaneko JJ, Harvey JW, Bruss ML. Clinical biochemistry of domestic animals. 6th ed. London: Elsevier; 2008.

Klaus R, Freitas KC, Silveira R, Barbosa AA, Pereira RA, Brauner CC, Corrêa MN, Rabassa VR. Caracterização molecular de isolados de escherichia coli em casos de diarreia neonatal bovina. Braz. J. Dev. 2020;6(6):40449-57. http://dx.doi.org/10.34117/bjdv6n6-545.

Knowles TG, Edwards JE, Bazeley KJ, Brown SN, Butterworth A, Warriss PD. Changes in the blood biochemical and haematological profile of neonatal calves with age. Vet Rec. 2000;147(21):593-8. http://dx.doi.org/10.1136/vr.147.21.593. PMid:11110479.

Léo VF, Campos DF, Dabus DM, Lima GS, Trentin TDC, Negri DD, Pereira DM. Farmacocinética e farmacodinâmica da associaçao das sulfas e trimetoprim. Rev Cient Elet Med Vet. 2009;7(12):1-7. 
Lopes CHAF, Chaves EMC, Jorge MSB. Administração de medicamentos: análise da produção científica de enfermagem. Rev Bras Enferm. 2006;59(5):684-8. http://dx.doi.org/10.1590/ S0034-71672006000500017. PMid:17340716.

Lorenzetti E, Stipp DT, Possatti F, Campanha JET, Alfieri AF, Alfieri AA. Diarrhea outbreaks in suckling piglets due to rotavirus group $\mathrm{C}$ single and mixed (rotavirus groups $\mathrm{A}$ and B) infections. Pesq Vet Bras. 2014;34(5):391-7. http:// dx.doi.org/10.1590/S0100-736X2014000500001.

McGuirk SM. Disease management of dairy calves and heifers. Vet Clin North Am Food Anim Pract. 2008;24(1):139-53. http://dx.doi.org/10.1016/j.cvfa.2007.10.003. PMid:18299036.

Moreira PC, Wascheck RC, Dutra AR, Grandsire C, Almeida OC, Moreira SDOL. Pectina: um carboidrato complexo e suas aplicações. Rev Cien Amb Saúde. 2008;35(3):343-55.

Opal SM, Pop-Vicas A. Molecular mechanisms of antibiotic resistance in bacteria. In: Bennett JE, Dolin R, Blaser MJ, editors. Mandell, Douglas, and Bennett's principles and practice of infectious diseases. 8th ed. Philadelphia: Elsevier; 2015. p. 234-51.

Papich MG. Saunders handbook of veterinary drugs: small and large animal. 4th ed. St. Louis: Saunders Elsevier; 2016.

Paton AW, Paton JC. Detection and characterization of shiga toxigenic Escherichia coli by using multiplex PCR assays for stx1, stx2, eaeA, enterohemorrhagic E. coli hlyA, rfb O111 and $r f b O 157$. J Clin Microbiol. 1998;36(2):598-602. http:// dx.doi.org/10.1128/JCM.36.2.598-602.1998. PMid:9466788.

Quinn PJ, Markey BK, Carter ME, Donnelly WJ, Leonard FC. Microbiologia veterinária e doenças infecciosas. Porto Alegre: Artmed; 2005. p. 47-49.
Renaud DL, Kelton DF, LeBlanc SJ, Haley DB, Duffield TF. Calf management risk factors on dairy farms associated with male calf mortality on veal farms. J Dairy Sci. 2018;101(2):1785-94. http://dx.doi.org/10.3168/jds.201713578. PMid:29248230.

Rosa F, Busato S, Avaroma FC, Linville K, Trevisi E, Osorio JS, Bionaz M. Transcriptional changes detected in fecal RNA of neonatal dairy calves undergoing a mild diarrhea are associated with inflammatory biomarkers. PLoS One. 2018;13(1):e0191599. http://dx.doi.org/10.1371/journal. pone.0191599. PMid:29373601.

SAS Institute INC. Cary, NC, EUA: SAS institute INC.; 2009.

Schukken YH, Bennett GJ, Zurakowski MJ, Sharkey HL, Rauch BJ, Thomas MJ, Ceglowski B, Saltman RL, Belomestnykh $\mathrm{N}$, Zadoks RN. Randomized clinical trial to evaluate the efficacy of a 5-day ceftiofur hydrochloride intramammary treatment on nonsevere gram-negative clinical mastitis. J Dairy Sci. 2011;94(12):6203-15. http://dx.doi.org/10.3168/ jds.2011-4290. PMid:22118109.

Spinosa HS, Górniak SL, Bernardi MM. Farmacologia aplicada à medicina veterinária. Rio de Janeiro: Guanabara Koogan; 2002.

Trefz FM, Lorenz I, Lorch A, Constable PD. Clinical signs, profound acidemia, hypoglycemia, and hypernatremia are predictive of mortality in 1,400 critically ill neonatal calves with diarrhea. PLoS One. 2017;12(8):e0182938. http:// dx.doi.org/10.1371/journal.pone.0182938. PMid:28817693.

Financial Support: Financial support COREMU Multiprofessional Residency Committee. 